University of Wollongong

Research Online

$1-1-2019$

\title{
An empirical study of relationships between goal alignment, centralised decision-making, commitment to networking and supply chain effectiveness using structural equation modelling
}

\author{
Dalal Albishri \\ da377@uowmail.edu.au \\ Balan Sundarakani \\ University of Wollongong, balan@uow.edu.au \\ Bostjan Gomisek \\ University of Wollongong Dubai
}

Follow this and additional works at: https://ro.uow.edu.au/dubaipapers

\section{Recommended Citation}

Albishri, Dalal; Sundarakani, Balan; and Gomisek, Bostjan: An empirical study of relationships between goal alignment, centralised decision-making, commitment to networking and supply chain effectiveness using structural equation modelling 2019.

https://ro.uow.edu.au/dubaipapers/1109 


\title{
An Empirical Study of Relationships between Goal Alignment, Centralised Decision Making, Commitment to Networking and Supply Chain Effectiveness Using Structural Equation Modelling
}

Dalal Yousuf Albishri ${ }^{1}$, Balan Sundarakani ${ }^{2 @}$, and Bostjan Gomisek ${ }^{3}$

\author{
${ }^{1}$ Doctoral Graduate, Faculty of Business \\ University of Wollongong in Dubai
}

Knowledge Village, Dubai, UAE - 20183

${ }^{2}$ Associate Professor, Faculty of Business, University of Wollongong in Dubai Knowledge Village, Dubai, UAE - 20183

@Email: Balansundarakani@uowdubai.ac.ae

${ }^{3}$ Associate Professor, Faculty of Business, University of Wollongong in Dubai Knowledge Village, Dubai, UAE - 20183

Abstract

The aim of this paper is to investigate the underlying factors of supply chain effectiveness of the networked organisations that are involved in the logistics industry in the UAE context. In particular, the study is to empirically test the relationships between goal alignment, commitment to networking and decision-making with four aspects of supply chain effectiveness. A systematic Literature review was conducted to identify the determinants of the supply chain effectiveness. The methodology employed in this study is primarily inductive in nature. A questionnaire-based survey was used to gather quantitative data from various supply chain organisations across industry verticals that are operating in the UAE. The data for this study were gathered and analysed employing survey responses from 154 representative organisations of various supply chain and logistics sector in the UAE. In this research, structural equation modelling has been applied to test these identified factors and their effect on supply chain effectiveness and its performance. The research discovered that the relationship between supply chain goal alignment, commitment to networking and decision-making were significantly and positively correlated with supply chain effectiveness. This 
research work advances theoretical examination into supply chain performance, as it the first research to empirically examine supply chain effectiveness through the lens of dimensions of a strategic supply chain. The findings provide insight into the field of supply chain effectiveness as part of supply chain performance. Several recommendations are offered for supply chain members to improve supply chain effectiveness while implementing dimensions of their strategic supply chain.

Keywords: Supply Chain Effectiveness, Supply Chain Performance measurement, Structural Equation Modelling,

Paper type: Research paper

\section{Introduction}

Supply chain is a management philosophy which includes planning, sourcing, manufacturing and transforming the raw material into finished goods and services and delivering these into the final customers through various intermediaries at the right time, at the right cost, at the right place in a damage free conditions (Fox et al. 2000). A typical organization comprises of distinct departments that manage the different parts of the supply chain. For example, purchasing takes care of the suppliers and the inventory of raw materials, operations takes care of manufacturing and the inventory of work-in-process and marketing manages demand and the inventory of finished products. When there is a lack of coordination between these departments, there are dramatic impacts on supply chain within and outside the organization (Yap and Tan, 2012). Therefore, measuring supply chain performance is the first step towards its strategic performance improvement.

Conventional supply chain performance measures were limited to cost minimization in the form of efficiency measures and customer excellence focused in the form of responsiveness (Handfield, et al. 2000; Moberg \& Speh 2003; Yap \& Tan 2012), however the effectiveness based measure are not sufficiently addressed. Many studies have clearly stated that there is a need to link the dimensions of Supply Chain Management (SCM) with organizational performance (Chen \& Paulraj 2004; Donlon 1996; Li et al. 2005; Tan et al. 2002). Furthermore, researchers such as Beamon (1999) suggest 'supply chain' is a complex term in itself, that involves various parties, such as, 
customers, distributors and suppliers. Beamon (1999) further argues that difficulties exist with respect to recognizing suitable performance aspects for supply chain analysis.

Additionally, it is acknowledged that since supply chain has organizational implications and it turns to be critical to evaluate the influence of SCM using an organization's performance measures (Green et al. 2006). It is also necessary to identify which aspects of SCM are associated with SCP and organisational performance, as the traditional supply chain construct has failed to consider the strategic supply chain dimensions (Albaloushi \& Skitmore 2008). Thus, it is believed that understanding the true dynamics of supply chains is far more complex than what most of the previous studies have shown. Although strategic supply chain performance is a key issue, still only few researches reported in the literature on this subject (Deshpande 2012; Kurniawan et al. 2017; Crook et al. 2008) and research on understanding Supply Chain Effectiveness (SCE) remains scarce (Kim et al. 2006; Kim \& Lee 2010). Most supply chain research analyses the rationale behind SCM or emphasises specific SCM practices. These three factors can be seen as a reflection of stakeholder and resource-based theories, which might be usefully taken into consideration when conceptualizing and improving supply chain effectiveness.

Traditional supply chain performance measures are limited to cost minimisation through efficiency measures and customer excellence in the form of responsiveness. However, effectiveness-based measures are not sufficiently addressed (Um \& Kim, (2019) and Shine et al. (2019). There is an overall scarcity of research on supply chain effectiveness and a lack of systematic discussion about the factors affecting supply chain effectiveness. This reveals a research gap regarding the under-representation of scholarly studies on supply chain performance within a United Arab Emirates (UAE) context as there has been very few research in this region (Sundarakani 2017, Sundarakani et al (2018) and Shqairat \& Sundarakani (2018)). This study aims to navigate beyond present research boundaries by establishing a thorough understanding of SCE, a key aspect of supply chain performance (SCP). Therefore, the main aim of our study was to answer the research question: Do Goal Alignment, Centralised Decision Making, Commitment to Networking and Supply Chain Effectiveness have impact on Supply Chain Effectiveness? Empirical testing of the mentioned relationships was performed using Structural Equation Modelling. The next section presents literature reviews to identify the research gaps in more detail. 


\section{Literature Review}

There is a significant body of literature related to supply chain practices. The existing literature identifies numerous supply chain dimensions, such as the optimisation of inventory, resources, information and technology and demonstrates how members of the supply chain are connected for common advantage (Bagchi et al. 2005; Cao \& Zhang 2011; Cao et al. 2010; Stavrulaki \& Davis 2010; Fantazy, Tipu \& Kumar 2016). Organisations need to align their business strategies and supply chain strategy. Further, Bowersox et al. (1999) added that supply chain members need to have strategic alignment for their supply chain to be effective. According to Sahay and Mohan (2003) and $\mathrm{Wu}$ et al. (2004), the extent of commitment throughout a supply chain decides overall SCE. Soosay et al. (2008) added that working together with supply chain members improves its effectiveness. Conversely, to achieve SCE, supply chain members need to understand the value of supply chain processes and supply chain success should be included in its members' goals (Deshpande 2012). Babbar et al. (2008) suggested that decision-making can influence SCE.

\subsection{UAE logistics industry sector}

The connection and shared dependence between collaborating organizations operating in an industry and value creation is turning to be increasingly crucial, not only to the existence and dynamism of the organizations and industries, but also critical to competitiveness and economic development of various nations (Sundarakani et al. (2019). This is crucial for oil-reliant economies such as the UAE that are looking for diversifying and growing their economies, maximizing their attractiveness, logistics industry competitiveness and industry performance (Knight Frank, 2018).

The UAE is considered as a business hub of the Middle East and is strategically located to serve the region and Africa, between Asia and Europe (Sundarakani, 2017). UAE is one of the biggest importers of Asian goods in the Middle East and therefore is also classed as a trans-shipment hub for the Middle East and North Africa (Sundarakani et al. 2018). The goods are usually imported from China and other Asian countries and then re-exported to African, European and CIS countries in small quantities. Apart from being in an ideal geographical location, UAE facilitates businesses by having strong social and economic links with Asia, Europe and Africa (eGovernment, 2019). 
In a globalized economy, SCM is a highly dynamic process, which carries enormous risks. The recent economic crisis had a huge impact on the global economy and its impact has been visible in the United Arab Emirates (UAE) as well (al-Suwaidi 2011). Organizations in the UAE are facing tremendous challenges in terms of both operations and profitability (Ashai et al. 2007). Supply chain and logistics are key industries in the economy of UAE and act as essential part of business in the UAE, given the small manufacturing base (Frost \& Sullivan 2017). A major portion of country's economy is based on the logistics industry and problems arising in this industry may have serious implications on the business community, logistical organizations and the overall economy of the UAE (Frost \& Sullivan 2017). This study will further add to the body of knowledge on the UAE logistics sector, which currently is not well researched. There were recent development in UAE logistics and supply chain industry and adoption of the new technologies; nevertheless little research has been done on dimensions of the strategic supply chain and their impact on performance. Moreover, this is the first research work to empirically test the effect of all three dimensions of strategic supply chain on supply chain effectiveness in UAE context.

\subsection{Relevant Theories}

Such empirical research needs critical to understand the theoretical foundation of the subject being investigated. To review SCM practices and provide a context within which to review the literature, a brief discussion of the theory guiding this study is presented. Despite the well-known appreciation of SCM's potential positive effects on organisational performance, there is considerable evidence that a discrepancy exists between theory and practice in its understanding and adoption. Research into supply chain theory proposes that a chain must be managed from 'end-to-end' but notes that 'our research found very few examples of this' (Storey et al. 2006, p. 763). Parallel to the growth of SCM our research was built predominantly upon the resource-based theory (Wernerfelt 1984, Barney, Ketchen, \& Wright 2011; Powell 2001).

The concept of competitive advantage has been treated extensively in the management literature. RBT is widely acknowledged as one of the most prominent and powerful theories for describing, explaining, and predicting organizational relationships (Barney, Ketchen, \& Wright, 2011; Powell, 2001).

According to RBT the basis for competitive advantage of a company lies in the application of bundle of valuable resources at the company's disposal (Wernerfelt, 
1984). The RBT addresses that the accumulation of valuable, rare, inimitable and nonsubstitutable (VRIN) resources is the basis of company's competitiveness and economic rent (Barney, 1986, Newbert, 2007). In RBT, company's resources are generally defined as all the assets, capabilities, processes and knowledge owned by the company, which in our case can be understood as "across the entire supply chain".

According to RBT, company's competitive advantage depends on its resources and how they are used (Shapiro, 1999). RBT theory proposes that organisations should be analysed based on their resources (Wernerfelt, 1984). If these resources can be classified as VRIN, they can lead to sustainable competitive advantage (Barney, 1991). Therefore, the more specific and difficult to copy these resources are, the more likely it is that sustainable competitive advantage can be built and maintained (Bessant et al., 2001). According to Barney (1991), if a resource or capability yields the potential to enable a company to reduce costs and/or respond to environmental opportunities and threats, it is valuable, and to the extent that a company is able to effectively deploy such a resource or capability, it will achieve a competitive advantage.

The RBT claims that a company that exploits its internal resources and capabilities could achieve a good performance, as the resources are stable and reliable in the process of strategic management, making the company able to face market dynamics and competition (Wilkens et al., 2004). As such, competitive advantage, under RBT perspective, is achieved by focussing on and exploiting a company's internal characteristics, specifically its resources profile (Savino \& Batbaatar, 2015). Barney (1991) divided resources into physical resources, human capital resources and organizational resources. According to RBT different kinds of resources give various contributions to the achievement of a sustained competitive advantage (Carraresi, Mamaqi, Albisu, \& Banterle, 2012); Fahy and Smithee (1999) classified resources as tangible assets, intangible assets and capabilities.

The above arguments clearly indicate that company's resources can contribute to higher performance outcome and lead to better competitive advantage. However, what makes a company competitive is not just the physical assets, but also its knowledge and how it behaves (Bessant et al., 2001). This means that intangible assets (e.g. know-how of employees, organizational culture, social capital, long-term customer relationships, etc.), and organizational capabilities (e.g. technology development, high quality production, high level of innovations, skills, new service development, strategy 
development, etc.) are important resources as well (Wernerfelt, 1984). As such, all assets, capabilities, organizational processes, company attributes, information, knowledge, etc. enable the company to implement strategies that improve its efficiency and effectiveness (Barney, 1991).

Research models of both an empirical and conceptual nature regularly emphasise relationship aspects of a strategic supply chain but use similar theoretical dimensions to describe the relationships, such as commitment, communication and collaboration (Dash et al. 2007) Amoako-Gyampah et al. (2019). Commitment is the need to continue relationships between organisations in a supply chain (Wilson 1995) and trust is an element that promotes alliance-based learning and flexibility by decreasing the necessity for a formal contract-based relationship (Taylor 2005). Network relationships ease information sharing, allowing supply chain members to gain access to resources, resulting in long-term relationships (Mikkola 2008). A network perspective suggests that organisations depend on both relations with their immediate associates and with the extended network of supply chain members (Michalski et al. 2019).

Krause et al. (2007) found support for a relationship between social capital in terms of perceived shared values among supply chain members and performance with respect to quality, cost, flexibility and delivery. These four dimensions of performance refer to effectiveness (one of the three aspects of performance) in this research. Significantly, in the absence of valuable resources or ways to obtain those resources, organisations might have trouble in profiting from strategic alliances (Hamel 1991). Therefore, social capital represents a significant concept for clarifying the cause for concern in strategic alliances (Matthews \& Marzec 2011). Social capital allows resources to flow without restriction to where they are required, leading to enhanced performance (Tsai \& Ghoshal 1998).

The theoretical background presented above prove sufficient ground that Goal alignment, commitment to networking and decision making has established their relation to supply chain effectiveness. The research suggests that there is a gap in the literature as there are no studies yet that links supply chain effectiveness to antecedent variables including goal alignment, commitment to networking and decision making. 
[Insert Figure 1 - here]

In an attempt to develop a theoretical model representing SCE, this research further examines the dimensions of SCP through comprehensive review as stated in Figure 1.

\subsection{Review on Supply Chain Effectiveness}

Performance measurement is defined as the process of measuring the efficiency and effectiveness of the carried out activities (Eonczuk 2016). Neely et al. (1995) suggest that effectiveness is the level of meeting to customer anticipations, whereas efficiency is a measure of the degree to which corporate assets are utilized to deliver a particular extend of customer satisfaction in addition to the bottom line. Realizing both has arisen as a challenge for organizations (Singh 2016). Even though the benefits of evaluating performance are well known, members of the supply chain have not took advantage of its full potential as they have failed to maximise both efficiency and effectiveness (Akyuz and Erkan 2010).

Okongwu et al. (2012, pp.11) describe SCE as "the effectiveness is to fulfil orders precisely as per customer's request or in other wards the completeness of customer orders and it can be measured in with respect to the percentage of the order that is completed within acceptable time frame by the customer". Therefore, SCE could be determined by various measures such as access to markets, performance of delivery, total cost, flexibility in realizing customer requirements, quality and ROI (Gunasekaran et al. 2001). The performance of delivery could be combined with other measures such as the order completion lead-time, request date delivery, and commitment date delivery. Therefore, in order to satisfy customer needs, supply chains have to exhibit a certain level of flexibility in the volume and range of services and products that can be accommodated. Another measure of effectiveness can be devised by the service delivery at the right quantity/level prescribed by customer with optimum transactions within the supply chain members.

More recently Eonczuk (2016) suggested that measuring the SCE is essential for better SCM. Further, SCE as part of SCP has an impact on the effective planning, monitoring and performing investigations of logistics processes. However, it's believed that SCE is understudied in the literature, leaving much unexplained in exploring the outcomes of 
inter-firm collaborations (Kim 2006; Kim \& Lee 2010). This research is an attempt in this direction to unearth the relationship existing among firms to have better SCP using SCE as performance measure. This study contributes to the literature of SCP by extending the analysis SCE a key aspect of SCP which is a principally challenging issue in a networked environment where organizations might have conflicting objectives and standpoints on performance.

\subsection{Effect of Alignment of Goals on SCE}

The extant literature suggest that in order for the organizations to ensure that both overall business and supply chain objectives are being achieved, it's essential for these organizations to align their general business strategies and their supply chain strategy (Sahay \& Mohan 2003). They also need to develop general firm-wide metrics in order to evaluate supply chain performance as well (Deshpande 2012). Many scholars recognize the role of organizational goals related to SCM and emphasis on the significance of top management's priorities that could have an important effect on an organization's overall effectiveness (Chen et al. 2004; Chen \& Paulraj 2004).

Coordination in supply chains ensures that its members perform as part of an integrated and aligned scheme that produces products or services (Arshinder et al. 2011). Ketchen and Hult (2007) suggested that alignment as an aspect of supply chain coordination is defined as a consistent fit among structures, activities and processes among supply chain members. Synchronisation in a supply chain is a strategic ability among its members to realise enhanced supply chain efficiency and to produce higher returns (Storer et al. 2013). Laihonen and Pekkola (2016) proposed that strategic focus enhances commitment to an organisation's shared and own goals and improves understanding of the relationship between separate and network-level goals.

An organization's goals could have crucial effect on supply chain activities including network and outsourcing decisions (Cross et al. 2005). Firms which face financial issues find it more challenging to concentrate on as well as make supply chain concerns a priority and, as a result, not realizing the effectiveness of the supply chain. Bowersox et al. (1999) suggest that supply chain members need to have strategic alignment. Xu and Beamon (2006) suggest that there is a need for coordination of supply chain member's actions in response to the strategic issues. Lee (2004) suggests that alignment 
is regarded as a key attribute of supply chain. In the light of the extant literature, this study proposes the following hypothesis:

$H_{1}$. Goal alignment in organisations has a positive influence on supply chain effectiveness.

\subsection{Effect of Commitment to Networking on SCE}

In the context of this research, several dimensions of a supply chain such as commitment to networking, integration and collaboration are utilised interchangeably (Cao \& Zhang 2011). Commitment is a broad concept that refers to organisations being dedicated to task effectiveness and supply chain members being dedicated to tasks and to each other. Commitment to networking in supply chain is essential and cooperation between supply chain members is considered as a key factor to manage supply chain networks effectively (Tyndall et al. 1998). As an essential feature of supply chains are the interdependence among members, it turns to be essential for multinational companies to show a genuine commitment for other supply chain members (Deshpande 2012). Commitment suggests that the trading members are prepared to dedicate energy to sustaining supply chain relationship (Dion et al. 1992). That is, committed members devote resources to sustain and further the objectives of the supply chain. To a large extend, commitment ensures that partners do not act in ways that could negatively influence overall SCP. Cooperation between members of the supply chain depends on the trust that results in supply chain performance improvement (Masudin et al. 2018).

Commitment ensures that supply chain members are integrated into their key customers' processes and tied effectively to their goals. The extent of both internal and external commitment throughout the supply chain decides the overall SCE (Sahay \& Mohan 2003; Wu et al. 2004). Researchers have demonstrated that if an organization is not devoted to its downstream suppliers, then communication activity throughout the supply chain could be impractical and inadequate (Prahinski \& Benton 2004) and the transaction's quality is inadequate. On the other hand, also having a supplier committed to its upstream customer is just as significant. The literature suggests that supply chain partners have to be committed to each other's for their supply chains to be successful. Improved collaboration between members of the supply chain and determining decision variables lead to increased supply chain performance (Dubey et al. 2017, Masudin et 
al. 2018). Besides, Mafini and Loury-Okoumba (2018) argue that continuous information sharing can be a key determinant of supply chain performance.

Many research show that commitment to networking including understanding, information sharing and communication (Chan \& Chan 2009; Chandra et al. 2007; Grossman 2004; Kampstra et al. 2006) - are critical in aligning supply chain toward shared objectives. Cooperation between members of the supply chain depends on the trust that results in supply chain performance improvement (Masudin et al. 2018). It is argued that collaboration and working together in the supply chain increase its effectiveness ( Min et al. 2005, Soosay et al. 2008). Taking into account present literature, this study proposes the following hypothesis:

$\mathrm{H}_{2}$. Commitment to networking throughout the supply chain has positive influence on supply chain effectiveness.

In the following section, the role of centralization of decision making on SCE is investigated.

\subsection{Effect of Centralized decision making on SCE}

It is important that coordination among organizations and supply chains carefully orchestrate while they are configuring their facilities around the world (Babbar et al. 2008). Throughout the supply chain, coordination necessities information flow as well as and materials flow. Supply chains in global environment are long and complex and this might result in various possible outcomes. Coordinating the activities of companies that are geographically dispersed could be challenging and difficult to achieve. Supply chain members that can enhance their performance are more likely capable minimizing their operation costs and eventually to improve the effectiveness of the whole supply chain (Mafini \& Loury-Okoumba 2018). However, making decisions in timely manner is crucial for supply chain partners to maximize the benefits.

Decision making in firms could be categorized to centralization or decentralization. Decision making is centralized when it is retained by top management. However, decision making is decentralized when it is disseminated throughout the firm where lower and middle management are authorized to take responsibilities and make decisions. SCM decisions could be generally classified as strategic (i.e. long-term 
decisions that link to corporate strategy concern the overall firm) and operational (i.e. short-term decisions that emphasis on the day-to-day activities of the firm). Further, Akdogan and Demirtas (2014) proposed three steps for an effective supply chain decision-making process. It starts with determining the strategies of a supply chain that define an organisation's strategy while realising all steps to offer products or services to customers.

At strategic level, decision making is focused on the general direction of the firm, it is anticipated that such decision should be centralized to permit a greater control. However operational decisions related to daily functions have to be decentralized in order to allow members of the supply chain to take decisions in fast and timely manner and to be able to handle local uncertainty. Hence it's unsurprising that firms try to make a balance between centralizing and decentralizing of decision making (Sabath \& Autry 2001). Furthermore, according to Sahay and Mohan (2003), in most developing countries, one of the main challenges reported related to operations is that a centralized structure makes it challenging to achieve the goals of supply chain. Literature further indicates that decentralization to be more effective when there are a large number of retailers (Abdul-Jalbar et al. 2003). At the operational level, a decentralized method is the favoured for decision making of a supply chain network (Deshpande 2012). In light of the literature presented for strategic supply chain decision making, this study proposes the following hypothesis:

H3. An effective decision-making mechanism has a positive influence on SCE.

\subsection{Research Gap}

Organisations implement supply chain best practices; however, there is evidence of supply chain failure (Arzu Akyuz \& Erman Erkan 2010). Most SCM literature focuses on the importance of a limited number of supply chain dimensions. It is believed that understanding the true dynamics of supply chains is far more complex than what most previous studies have shown.

This research aims to establish a comprehensive understanding of SCE, one of the key aspects of SCP. Okongwu et al. (2012) outlined that SCP consists of three key dimensions: effectiveness, efficiency and responsiveness. The authors indicated that it is important that all three different dimensions of SCP are appropriately considered to 
capture the performance of a chain. This study focuses on the effectiveness dimension of SCP, which is essential for better SCM; efficiency and responsiveness have already been studied in the supply chain literature (Leonczuk 2016). Further, SCE is a key part of SCP, which is believed to be understudied in the literature (Kim et al. 2006; Kim \& Lee 2010). Supply chain members that can enhance their performance are more likely capable minimizing their operation costs and eventually to improve the effectiveness of the whole supply chain (Mafini \& Loury-Okoumba 2018).

The literature has not adequately reported on SCP and research into realising SCE remains scarce. There is an overall scarcity of investigation into SCE and the systematic discussion of dimensions of a strategic supply chain that affect SCE (Kim et al. 2006; Kim \& Lee 2010). There are constant threats to the UAE's supply chain, such as political unrest in neighbouring countries, over-capacity and drops in demand that continually threatening to push down rates and impinge on profits. Difference in cultural, business, organisational factors attribute varying supply chain collaboration and commitment to networking aspects in the UAE. The UAE has its own logistical and supply chain related issues that affect day to day operations of firms than other established market. Therefore, Firms need to find methods of collaboration that maybe different from those used by firms in other countries. Further, there is an underrepresentation of scholarly research on this subject within a UAE context, thus necessitates need for this research. Table 1 presents a summary of the research gaps.

[Insert Table 1 here]

Previous research has suggested three dimensions to a strategic supply chain-goal alignment, commitment to networking and decision-making-might have an influence on SCE. These variables were sporadically captured by Deshpande (2012) but have not been empirically investigated to date. This is the first study to empirically test the effect of all three strategic supply chain dimensions on SCE. 


\section{Theoretical Framework}

The framework builds upon resource-based theory (RBT) literature to develop a conceptual framework, mainly to understand how supply chain members (resources) could contribute to SCE.

Theoretical development considers the relationships among comprehensive ranges of acknowledged variables and classifies goal alignment, commitment to networking and decision-making as potential variables that may influence SCE. This research attempts to address the research gaps by empirically investigating these three dimensions through the theoretical framework presented in the following section.

The framework presented in Figure 2 exhibits the research model describing the main constructs discussed in literature review. The framework establishes direct, positive relationships between goal alignment, commitment to networking, the centralisation of decision-making and SCE. The dependent variable, SCE, will be measured through four measurement metrics consisting of cost, flexibility, delivery and quality. The next section discusses the research method employed to statistically test the hypotheses and conceptual model.

[Insert Figure 2 here]

\section{Research Method}

To test the research hypotheses, a cross-sectional research method was employed based on a self-administered questionnaire. Sudman, Bradburn and Schwarz (1996) argued that self-administered questionnaires are employed widely and surveys are considered the most popular form in which to collect data. Kerlinger (1992) suggested that this approach is beneficial in collecting a great deal of information and when excessive time limits on data gathering do not exist. Surveys are appropriate and realistic compared to experimental research designs (Kerlinger 1992) and are more cost effective (Dillman 1978). Thus, this approach was considered an appropriate choice for this research to gather the required data. In order to achieve high levels of reliability and validity, the 
scale development process was used to develop the questionnaire as highlighted in Table 2.

[Insert Table 2 - here]

The instrument to measure SCE (i.e., dependent variable) was adopted from previous valid and reliable studies with slight modifications (Miguel \& Brito 2011; Yim \& Leem 2012). The constructs goal alignment, commitment to networking and decision-making (i.e., independent variables) were newly developed in this research. Thus, the instrument used to measure these constructs was developed based on the critical review of the relevant literature. The construct items based on the theoretical constructs were developed from the literature review presented above.

The questionnaire was developed with reference to existing questionnaires, the literature review and a number of existing pre-established scales and focused on various SCM issues that were applicable to the SCE construct. With respect to the dependent variable, respondents were asked to indicate the importance of the performance measures: cost, flexibility, delivery and quality (Germain et al. 2001; Miguel \& Brito 2011). These indicators were measured using five-point Likert scales with anchors ranging from below average (1) to above average (5) as shown in constructs Table 3.

[Insert Table 3 here]

A non-probability sampling technique was the practical choice for this study. According to Babbie (2007), this sampling technique is selected because it is adequate when absolute accuracy is not significant but frequently results in a sample very similar to the population of interest. Researchers have recommended that the calculation of a sample size be undertaken by multiplying by 20 times the number of variables (Weiss 1972; Lindeman, Merenda \& Gold 1980; Stevens 1996). Therefore, the sample size for the survey used in this study should be 140 (i.e., seven variables x 20). The likely variables were the three independent variables (i.e., goal alignment, commitment to 
networking and decision-making) and one dependent variable, SCE, which consists of the four sub-variables of quality, cost, flexibility and delivery.

\subsection{Data Collection}

Questionnaire was distributed by both online version and the paper based along with the participant information sheet. As a later month, several follow-up calls were made to the participating organizations. A total of 154 complete surveys were collected. Screening of data sets was performed by examining basic descriptive statistics and frequency distributions. The most important step in data screening is to detect values that were improperly coded or out-of-range (Pallant 2011). This was conducted by running a frequency test for every variable to detect these values. Data were screened and cleaned from the effects of missing data and outliers, and the main assumptions underlying multivariate techniques such as normality, homoscedasticity and linearity were tested. Missing data were replaced by corresponding mean. No outliers were detected as a 5 point scale was used. The results of this test did not detect any out-ofrange or improperly coded response.

\subsection{PLS-SEM model design}

According to Chin \& Newsted (1999), linear structural relations have limitations when employed for testing complex models that have sample size restraints. Conversely, PLS is capable of examining complex models. Cassel et al. (1999) suggested that PLS is vigorous against deviances from a normal distribution. Unlike Covariance Based SEM (CBSEM), PLS deals with factor indeterminacy issues, copes better with formative measures and handles small sample sizes (Falk \& Miller 1992; Fornell \& Bookstein 1982; Wittingslow \& Markham 1999). Generally, there is a common understanding that a larger sample size provides better/more stable parameter estimates of PLS modelling activities; however, there is no clear understanding in regard to "large enough" sample size (Macroulides \& Saunders, 2006). For example, Chin and Newsted (1999) showed that small sample sizes $(\mathrm{N}=20)$ were not allowing to determine structural path coefficients of low value $(0.20)$; the results become viable with larger sample sizes $(\mathrm{N}$ $=150$ to 200). Moreover, researchers reported that PLS estimates improved and their average absolute errors decreased hen using bigger sample sizes (Hui and Wold, 1982). 
Following Bentler (1995) or Hu et al. (1992) one should take care that the sample size is bigger than ten (10) times the number of free model parameters. However, Chin (1998) pointed out that a rule of thumb of 10 per predictor can be used under the following conditions: The sample size will be ten (10) times bigger than (a) the construct with the largest number of indicators (measurement equation) or (b) the dependent variable with the largest number of independent variables impacting it (structural equation). In our case the first is six (6) and the second is seven (7) with an overall sample size of 154 .

Moreover, to control the precision of estimation and define standard errors in our PLS modelling activities, we used the bootstrapping (Chin, 1998; Denham, 1997). Based on Macroulides \& Saunders (2006) discussion on the appropriate sample size in regard to "the including the psychometric properties of the variables, the strength of the relationships among the variables considered, the complexity and size of the model, the amount of missing data, and the distributional characteristics of the variables considered" we assume that our sample size was sufficient for model to provide with sound parameter estimates.

However, PLS can be utilized for both exploratory and confirmatory applications, as it does not attempt to go beyond the data (Ringle et al. 2012). According to Bontis and Booker (2007), in PLS, constructs can be evaluated by a single item while in covariance-based techniques; at least three items per construct are needed (Hair et al., 2010). They further claim that in most marketing research, data tend to be non-normally distributed and PLS handles non-normal distributions comparatively well as it does not necessitate any normality assumptions. They add, PLS accounts for measurement error and could offer extra accurate estimates of interaction effects such as mediation (Chin 1998). Furthermore, PLS results have been proven to be robust against multicollinearity. PLS can mitigate the multicollinearity issue in the data and limit the potential bias in the results (Hair et al. 2014). PLS is able analyse models that contain both reflective and formative constructs (Gefen et al. 2011). Selecting PLS as a modelling method was justified by the current research, which shows that predictive and theory building studies are usually challenged by small sample sizes and can be prone to incorrect outcomes (Reinartz et al. 2009).

As this study is exploratory in nature, investigates a complex model with higher-order abstract relationships and comprises a smaller sample size than what a covariance-based 
model could manage, it was considered practical to choose the technique that best managed these issues. Therefore, the key rationale is discussed as follows:

1. The exploratory nature of the research suited PLS modelling (Bagozzi \& Yi, 1994; Chin, 1998).

2. The complexity of a model is intensified when testing relationships that are classified as having higher-order abstract relationships.

3. PLS can better deal with formative measures (Anderson \& Gerbing 1988). In this study, SCE was a second-order formative measure that required the use of PLS.

4. This study emphasized causative predictive investigation; that is, the effect of goal alignment, commitment to networking and decision-making on SCE.

5. PLS can deal with smaller sample sizes (Hair et al, 2014). The sample size in this study was only 154 cases, which is smaller than a covariance-based model could manage (Hair et al, 2014).

6. PLS tackles non-normal distributions well, as it does not demand any normality assumptions (Bontis \& Booker 2007).

7. PLS results are robust against multicollinearity (Cassel, 2000) and Hair et al. (2014b).

\subsection{Normality and convergent validity}

Testing the effect of the normality assumption violation is very important, as it can affect the final results and, as suggested by Kerlinger and Lee (2000), result in questionable conclusions drawn from the sample. The skewness and kurtosis tests are used to validate normality (Pallant 2011). In the current research, the distribution was normal, the absolute values of skewness were below two and the absolute values of kurtosis were below three (Newsom, 2005).

\subsection{Construct Validity and Reliability}

It was significantly essential to evaluate the validity and reliability of the questionnaire in the UAE context because it was developed from literature. In order to verify the internal consistency of the constructs, Cronbach's alpha was used to measure the reliability of the scales as shown in tables 3 and 4 . Cronbach's alpha of 0.70 and above was considered as acceptable. All factors had acceptable scale reliabilities based on 
Cronbach's (1951) criterion suggesting a coefficient of 0.70 or above as adequate. Reliability coefficients were $0.92,0.92$ and 0.89 for Goal Alignment, Commitment to Networking and Decision Making, respectively. Reliability coefficients for supply chain effectiveness constructs were $0.79,0.85,0.75$ and 0.86 for Flexibility, Cost, Quality and Delivery, respectively.

\subsection{Factor analysis - EFA and CFA}

In order to explore the factor structure of the measures in this research, both exploratory factor analysis (EFA) and confirmatory factor analysis (CFA) were conducted. EFA was used to extract factors that served as the anticipated measurement model in the CFA. CFA then was used to test the fitness of the proposed model with the acquired data (Hair et al. 2010).

Factor analysis was completed utilizing SPSS 23 using the principal components factoring technique with varimax rotation. Some of the items had small loadings or did not load to any factor. Two criteria were employed with regards to the decision of including or excluding items in scales. First, according to Hair et al. (2014), items with loading score less than 0.40 were perceived as weak thus they were excluded from further analysis. Then items cross-loading on two separate factors with a loading score less than 0.40 on one factor, it was also excluded. Eight of the fourteen items of Goal Alignment, eighteen of the twenty four items of Commitment to Networking and nine of the twelve items of Decision Making were excluded from the analysis.

Fabrigar et al. (1999) suggests that principal axis method is a more robust extraction method against the violation of the normality assumption. Hence it was used for the factors extraction. The Kaiser-Meyer-Olkin (KMO) measure of sampling adequacy and the Bartlett test of sphericity were employed to determine sampling adequacy (Kim \& Mueller 1978). The KMO values close to 1 indicate the appropriateness of factor analysis. The Bartlett test of sphericity values should be less than 0.05 to propose that there are possibly significant relationships between the constructs. 
After excluding items that did not load to any factor, the other items were soundly represented by the three factors. The factors identified were internally consistent and well identified by their corresponding items. The item loadings on factors and the explained variance are presented in Table 2. The KMO measure was equal to 0.911 and Bartlett's test of sphericity was significant (chi-square $=1768.108, \mathrm{df}=105, \mathrm{p}<0.001$ ). These measures regarded as acceptable to proceed with factor analysis. Principal axis factoring of extracting factors revealed the presence of three factors with eigenvalues larger than one accounting for $74 \%$ of the variance as shown in Table 4 . Factor 1 consisted of 6 items from the Goal Alignment variable, factor 2 consisted of 6 items from the Commitment to Networking variable and factor 3 consisted of 3 items from the Decision Making variable.

[Insert Table 4 here]

\subsection{EFA of Supply Chain Effectiveness}

Similarly, with a cut of point of 0.40 , three of the seven items of Flexibility, two of the five items of Cost, two of the five items of Quality and one of the five items of Delivery were excluded from the analysis. The KMO measure was equal to 0.896 and the test of sphericity was significant (chi-square $=1103.7$, df $=105, \mathrm{p}<0.001$ ). Both these measures suggested that factor analysis was suitable to proceed with factor analysis. Principal axis factoring of extracting factors revealed the presence of four factors with eigenvalues larger than one accounting for $70 \%$ of the variance as shown in Table 5 . The factor 1 included 4 items from Flexibility, factor 2 included 3 of Cost items, factor 3 included 3 of Quality items and factor 4 included 4 of Delivery items.

[Insert Table 5 here]

\section{PLS Measurement and Structural model}

The selection of the PLS was based on a thorough considerations of its advantages and disadvantages over other SEM models. According to Chin \& Newsted (1999), LISREL 
have limitations when employed for testing complex models that have sample size restraints. PLS on the other hand, is able of examining complex models (Chin 1998) and almost every time converges (Wold 1981). Cassel et al. (1999) suggest that PLS is vigorous against deviances from the normal distribution. Unlike CBSEM, PLS deals with factor indeterminacy issue, copes better with formative measures and handles better small sample sizes (Falk \& Miller 1992, Fornell \& Bookstein 1982, Wittingslow \& Markham 1999). As this study is exploratory in nature, investigates a complex model with higher-order abstract relationships, and the sample size is smaller than what a covariance based model could manage, it was considered reasonable to choose the PLSSEM.

Tenenhaus et al. (2005) suggest a Goodness-of-Fit (GoF) measure for PLS. A goodnessof-fit index (GoF) is "an operational solution to this problem as it may be meant as an index for validating the PLS model generally" (Tenenhaus et al. 2005). According to them, GoF is based on calculating the square root of the product of the variance extracted with all constructs with multiple indicators and the average $\mathrm{R}^{2}$ value of the endogenous constructs (Tenenhaus et al. 2005). According to Cohen's (1988) categorizations, GoF measure is calculated of between 0 and 1 using a cut-off value of 0.50 for various communality . The GoF measures were 0.60 for the model. Generally, this result in Figure 3, suggest very good fit proposing that the model has good explanatory power in sample and the measurement model was stabile as well.

[Insert Figure 3 here]

The measurement model was evaluated to see if it held for the sample. Some items were removed until the several diagnostics shown that the constructs were adequately explained. Cronbach's alpha $(\alpha)$ and composite reliability (CR) scores were used to assess the internal consistency. Reliability scores for all constructs exceeded the threshold of 0.70 for Cronbach's $\alpha$ (Nunnally 1978) and CR values were above the threshold of 0.8 (see Table 6), which according to Hair et al. (1998) are sufficient to establish high internal consistency.

[Insert Table 6 here] 
The EFA offered support to identify the factor structure for following CFA testing. The AVE scores were used to test the convergent validity for the CFA which should exceed the threshold of 0.5 (Fornell \& Larcker 1981; Hair et al. 1998). The AVE scores for all variables in this study ranged from 0.63 to 0.80 . Besides every indicator showed significant loading on its respected variable which indicated high convergent validity. Fornell \& Larcker (1981) technique was used to test if the constructs have adequate discriminant validity. Every indicator loaded higher on its relative variable than on any other variable in the model, indicating satisfactory discriminant validity (Gefen \& Straub 2005). See Table 7 for more details.

[Insert Table 7 here]

Based on the recommendation by Efron and Tibshirani (1993), 500 was the number of samples set in the bootstrapping. The findings of this study are consistent with and without the control variables. Besides none of the three control variables (firm age, firm size and industry) had a statistically significant effect $(\mathrm{p}<0.05)$ on the dependent variable supply chain effectiveness.

Hypotheses seek either to describe a phenomenon or a probable correlation between multiple phenomena (Gravetter \& Wallnau 2007). In this study, three hypotheses were established and tested through various statistical techniques at a 95 per cent confidence level $\left(\alpha=.05^{*}\right)$ and 99 per cent confidence level $\left(\alpha=.01^{* *}\right)$. The hypotheses were tested using a SEM approach and SmartPLS 3.1 software. Table 8 presents the hypotheses testing outcomes.

[Insert Table 8 here]

The following sections discusses the hypotheses statements, chosen statistical technique, test results and related interpretations.

Hypothesis 1 Investigated the relationship between goal alignment and supply chain effectiveness:

In terms of the relationship between Goal Alignment and Supply chain effectiveness, the results indicated that Goal Alignment was significantly and positively correlated 
with Supply chain effectiveness. The path between Goal Alignment and Supply chain effectiveness was statistically significant $(\mathrm{p}<0.01)$ and in the hypothesized direction supporting $\mathrm{H}_{1}$. As expected, Goal Alignment has a significant positive influence on supply chain effectiveness $(\beta=0.23, \mathrm{t}=2.70)$. The result is consistent with hypothesis $\mathrm{H}_{1}$ that goal alignment is positively associated with supply chain effectiveness.

Hypothesis 2: Examined the relationship between commitment to networking and supply chain effectiveness:

In terms of the relationship between Commitment to Networking and Supply chain effectiveness, the results indicated that Commitment to Networking was significantly and positively correlated with Supply chain effectiveness. The path between Commitment to Networking and Supply chain effectiveness was statistically significant $(\mathrm{p}<0.01)$ and in the hypothesized direction supporting $\mathrm{H}_{2}$. As expected, Commitment to Networking has a significant positive influence on supply chain effectiveness $(\beta=$ $0.19, \mathrm{t}=3.22)$. The result is consistent with hypothesis $\mathrm{H}_{2}$ that Commitment to Networking is positively associated with supply chain effectiveness.

Hypothesis 3 Investigated the relationship between decision making and supply chain effectiveness:

In terms of the relationship between Decision Making and Supply chain effectiveness, the results indicated that Decision Making was significantly correlated with Supply chain effectiveness. The path between centralisation of decision making and Supply chain effectiveness was statistically significant $(p<0.01)$ and in the hypothesized direction supporting $\mathrm{H}_{3}$. Therefore, centralisation of decision making has a significant positive influence on supply chain effectiveness $(\beta=0.12, \mathrm{t}=2.37)$. The result is consistent with $\mathrm{H} 3$ that decision-making is positively associated with SCE.

\section{Findings and Discussions}

This research was guided by the research objective to examine the effect of dimensions of a strategic supply chain on SCE. The following are the key findings attained from analysing the collected data. With regards to strategic supply chain dimensions, it was found that goal alignment, commitment to networking and decision-making were positively related to SCE. The results of this research indicate that participants 
perceived higher levels of goal alignment and commitment to networking compared to decision-making. Therefore, it is recommended that supply chain members should focus on quality and delivery aspects, as they are primarily used to meet SCE.

The connection and shared dependence between collaborating organisations that operate in an industry and value creation is increasingly crucial to the existence and dynamism of organisations and industries and the competitiveness and economic development of various nations (Leonczuk 2016). This is essential for oil-reliant economies such as the UAE that seek to diversify and grow their economies, maximising their attractiveness and industry performance (eGovernment 2012). Organisations hardly succeed in isolation; rather, they are reliant on larger entities within their field of business (Deshpande 2012). It is obvious that UAE sectors have been successful because value creation has been dependent on an intensive infrastructure approach but this value might be critical, as it is replicable by other countries seeking to adapt a similar model (Frost \& Sullivan 2011). It is on this premise that this research seeks to examine the role of goal alignment, commitment to networking and decision-making, emphasising the UAE supply chain and logistic sector.

The framework for this research was underpinned by the RBT due to its relevance in the context of supply chain management constructs and the phenomenon under study. Goal alignment, commitment to networking and decision-making were the three SCM practices that were found to have the most potential to contribute to SCE and were included in this research. SCE remains a matter that has serious effects on both members of a supply chain and the supply chain as a whole (Singh 2016). Enhanced performance of supply chain members is important and a lack of effectiveness is an issue because of its effect on the success of supply chain initiatives. The results of this research suggest that SCE was advanced when there existed a better alignment of goals, enhanced networking between supply chain members and an effective decision-making mechanism.

The results specify that dimensions of a strategic supply chain significantly influence its effectiveness. To make a supply chain effective, the focus should be on effective and efficient goal alignment, commitment to networking and decision-making. This can be realised by aligning an individual organisation's goals with the goals of other supply chain members, working together as a network by collaborating and cooperating and 
having an effective decision-making mechanism. Researchers have argued that supply chain members need to have strategic alignment by aligning both their general business and supply chain strategies (Bowersox et al. 1999; Sahay \& Mohan 2003). Many researchers considered commitment to networking in terms of collaboration a key dimension to effectively manage supply chain networks and to increase its effectiveness (Clark \& Lee 2000; Min et al. 2005; Soosay et al. 2008; Tyndall et al. 1998; Prahinski $\&$ Benton 2004). Conversely, researchers such as Sahay and Mohan (2003) argued that a centralised structure makes it challenging to realise the goals of a supply chain.

Based on the research model, it is suggested that the use of dimensions of a strategic supply chain goal alignment, commitment to networking and decision-making-increase SCE and, thus, enhance its performance. The findings of this research show that enhanced networking between supply chain members, an effective decision-making system and, most importantly, better alignment of goals, will enhance SCE. It is argued that for a supply chain to be effective, its members have to align their goals with the overall goals of the supply chain (Deshpande 2012). Having an effective decisionmaking mechanism will enhance decision-making and, consequently, SCE.

As discussed earlier, goal alignment and commitment to networking are the key to improving SCE and, thus, SCP. These two strategic supply chain dimensions added a distinctive variance to the results in relation to SCE. The findings of this study undoubtedly show that goal alignment and commitment to networking are significantly related to SCE, which affects overall SCP. Setting common goals, aligning individual goals and collaborating and cooperating effectively throughout a supply chain lead to enhanced SCE. This confirms the need for supply chain members to focus on goal alignment and commitment to networking to make their supply chain more effective, including those operating in the UAE. The result for goal alignment showed that it had a significant impact on supply chain effectiveness. In fact, goal alignment was found to be the most influencing supply chain practice. Another contribution of this study was proven significance of the role of commitment to networking in a supply chain effectiveness, based on empirical support to this relationship. We might conclude that if decision-making is not disseminated throughout the firm where lower and middle management are authorized to take responsibilities and make decisions then it is going to affect the performance of the supply chain. 
The results of this research offer a detailed understanding of the effects of strategic supply chain dimensions and practices by finding positive relationships between all three dimensions (i.e., goal alignment, commitment to networking and decisionmaking) and SCE. Being able to empirically test and prove the effects of these three dimensions is considered unique to this study. Further, this is considered the first study to test all three variables together. The output of this research presents researchers in the supply chain field with a novel way to measure SCE by establishing a model of dimensions of a strategic supply chain that contribute to SCE. A unique feature of this model is that it is the selection stage of these dimensions that drives SCE. A key contribution of this research is the development of a comprehensive theoretical framework and validation of hypotheses that recognise the relationships between strategic supply chain dimensions and SCE. Further, this research offers a newly developed questionnaire with measuring scales for all three dimensions that were measured in this study.

Implications for practice might be demonstrated by the results which should encourage supply chain managers generally and in individual organisations to focus more on dimensions of the strategic supply chain that contribute to the effectiveness of supply chain. Having dimensions of the strategic supply chain linked with effectiveness of the supply chain, the developed framework will assist supply chain practitioners to be further sensitive to the significance and difficulties of handling the considered three dimensions of strategic supply chain.

\section{Conclusion}

This study has synthesized the large body of knowledge into external and internal factors affecting supply chain effectiveness as performance measurement metric. This study has provided the evidence that most supply chain literature has emphasized on the importance of only traditional metric such as efficiency (Deshpande, 2012). Therefore, warrant need for having a holistic metric such as effectiveness as measure by understanding the dynamics which is more complex than most of these researches have offered. The managerial implication of the results is that they encourage supply chains in general and individual organisations in particular to focus more on dimensions of a strategic supply chain that contribute to SCE. Doing this will likely establish a performance-driven culture that will also enhance SCP in the long term. 
The comparative significance and interrelationships of different SCM initiatives, practices, activities and constructs as well as their direct effects on supply chain performance generally and supply chain effectiveness particularly have been investigated in this research in the UAE. Suitable selection of factors and dimensions of supply chain that affect supply chain effectiveness help to recognize problematic areas and is essential in managing the supply chain in a turbulent environment and competitive global markets. This in turn offers the required information for decisionmakers. The suggested set of factors including goal alignment, commitment to networking and decision making can be used to assess the effectiveness of a modern supply chain as performance measurement metrics.

Several future research directions exist. The research findings suggest that direct relationships do exist between various practices of a supply chain and SCE however indirect relationships such as moderation and mediation can further enrich the findings. However, additional investigation is required to more thoroughly inspect the complexities of the relationships. Future research can be directed to developing an instrument to measure the comparative degree of SCE. Detailed discussions on dimensions of a strategic supply chain as presented in this research can facilitate the identification of potential measures for these dimensions. Innovative statistical methods, including SEM can be applied to recognise which attribute further influence SCE.

Future research will highly benefit from reviewing previous studies with respect to the determinants of supply chain strategy and its relationship with performance dimensions considered in this research study and in depth meta-analysis of theories considered to bridge the link between strategy, process and performance. Besides, the fact that the chosen dimensions are not exhaustive suggests that further research into strategic supply chain dimensions is required. Future research is also possible by extending the findings of this study to determine other aspects of SCE. Additionally, this study's results offer valuable understanding for supply chain experts, who should focus on realising how to strategically manage a supply chain through goal alignment, enhanced networking and an effective decision-making system.

Many future research questions can arise to progress the understanding of SCE, such as, 'Which dimensions of a strategic supply chain are more likely to have a strong effect 
on the level of SCE when they are interrelated?' Furthermore, future research can consider arbitration of effectives in achieving certain dimensions and it advancement to conventional theories that has been previously studied to gain competitive advantage. Moreover, investigating the unique influence of each strategy attribute in supply chain effectiveness and supply chain performance is considered as another potential area for future research.

\section{References}

Abdul-Jalbar, B, Gutierrez, J, Puerto, J \& Sicilia, J 2003, "Policies for inventory/distribution systems: the effect of centralization vs. decentralization", International Journal of Production Economics, vol. 81/82, no. 1, pp. 281-93.

Akdogan, A \& Demirtas, O 2014, "Managerial Role in Strategic Supply Chain Management", Procedia - Social and Behavioral Sciences, vol. 150, pp. 10201029.

Akyuz, G \& Erkan, T (2010), 'Supply chain performance measurement: a literature review'. International Journal of Production Research, vol. 48, no. 17, pp. 5137 5155.

Albaloushi, H \& Skitmore, M 2008, "Supply chain management in the UAE construction industry”, International Journal of Construction Management, vol. 8, no. 1, pp. 53-71.

Amoako-Gyampah, K., Boakye, K. G., Adaku, E., \& Famiyeh, S. (2019). Supplier relationship management and firm performance in developing economies: A moderated mediation analysis of flexibility capability and ownership structure. International Journal of Production Economics, 208, 160-170

Anderson, J \& Gerbing, D 1988, “Structural Equation Modeling in Practice: A Review and Recommended Two - Step Approach”, Psychological Bulletin, vol. 103, pp. 411-423. 
Arzu Akyuz, G \& Erman Erkan, T 2010, "Supply chain performance measurement: a literature review", International Journal of Production Research, vol. 48, no.17, pp.5137-5155.

Babbar, S, Addae, H, Gosen, J \& Prasad, S (2008),"Organizational factors affecting supply chains in developing countries", International Journal of Commerce and Management, Vol. 18 Iss: 3 pp. 234 - 251

Babbie, E (ed.) 2007, The practice of social research, 11 edn, CA: Thomson Wadsworth, Belmont.

Bagchi, P \& Skjoett-Larsen, T 2002, "Integration of Information Technology and Organizations in a Supply Chain", International Journal of Logistics Management, vol. 14, pp. 89-108.

Bagozzi, R \& Yi, Y 1994, Advanced topics in structural equation models. In R. P. Bagozzi (Ed.), Advanced methods of marketing research (pp. 1-52). Cambridge, MA: Blackwell.

Barney J.B., Ketchen D.J., Wright M., The Future of Resource-Based Theory, Journal of Management 37(5), 2011, pp.1299-1315

Barney, J. (1991). Firm resources and sustained competitive advantage. Journal of Management. 17(1), 99-120.

Barney, J. B. (1986). Strategic factor markets: Expectations, luck, and business strategy. Management Science, 32(10), 1231-1241.

Beamon, B 1999, 'Measuring supply chain performance'. International Journal of Operations \& Production Management, vol. 19, no. 3, pp275-292.

Bentler, P. M. EQS Structural Equation Program Manual, Multivariate Software Inc., Encino, CA, 1995

Bessant, J., Caffyn, S., \& Gallagher, M. (2001). An evolutionary model of continuous improvement behaviour. Technovation, 21(2), 67-77.

Bontis, N, Booker, L \& Serenko, A 2007, "The mediating effect of organizational reputation on customer loyalty and service recommendation in the banking industry", Management Decision, vol. 45 no. 9, pp.1426-1445.

Bowersox, D, Closs, D \& Stank, T 1999, 21 st Century Logistics: Making Supply Chain Integration a Reality, Council of Logistics Management, Oak Brook, IL.

Bowersox, D.J. (1990). The Strategic Benefits of Logistics Alliances. Harvard Business Review, (July-August), 68, (4), 36-45. 
Boyer, K \& Morgan L 2008, 'Empirical elephants —-why multiple methods are essential to quality research in operations and supply chain management', Journal of Operations Management, vol. 26, no.3, pp.338 - 344.

Cao, M \& Zhang, Q 2011, 'Supply chain collaboration: Impact on collaborative advantage and firm performance', Journal of Operations Management, vol.29, no.3, pp. 163-180.

Carraresi, L., Mamaqi, X., Albisu, L. M., \& Banterle, A. (2012). Strategic capabilities and performance: an application of resource-based view in Italian food SMEs. Proceedings in Food System Dynamics, 186-209.

Cassel, C, Hackl, P \& Westlund, A 2000, "On Measurement of Intangible Assets: A study into the Robustness of Partial Least Squares", Total Quality Management, vol. 11, no. 7, pp.897-908.

Chan, H.K. and Chan, F.T.S. (2009), "Effect of information sharing in supply chains with flexibility", International Journal of Production Research, Vol. 47 No. 1, pp. 213-232

Chandra, C., Grabis, J. and Tumanyan, A. (2007), "Problem taxonomy: a step towards effective information sharing in supply chain management", International Journal of Production Research, Vol. 45 No. 1, pp. 2507-2544.

Chen I. J., \& Paulraj, A. (2004b). Understanding supply chain management: critical research and a theoretical framework. International Journal of Production Research, 42(1), 131-163.

Chen, I. J., Paulraj, A., \& Lado, A. A. (2004). Strategic purchasing, supply management and firm performance. Journal of Operations Management, 22(5), 505-523.

Chen, I., \& Paulraj, A. (2004a). Towards a theory of supply chain management: the constructs and measurements. Journal of Operations Management, 22(2), 119150 .

Chin, W \& Newsted, P 1999, Structural Equation Modelling Analysis with Small Samples Using Partial Least Squares, in R.H. Hoyle (Ed.) Statistical Strategies for Small Sample Research, Sage Publications, Thousand Oaks, CA, 1999, 307341.

Chin, W. W. "The Partial Least Squares Approach for Structural Equation Modeling," in Modern Methods for Business Research, G. A. Marcoulides (ed.), Lawrence Erlbaum Associates, Mahwah, NJ, 1998, pp. 295-336 
Chin, W. W., and Newsted, P. R. "Structural Equation Modeling Analysis with Small Samples Using Partial Least Squares, "In Statistical Strategies for Small Sample Research, R. H. Hoyle (ed.). Sage Publications, Thousand Oaks, CA, 1999, pp. 307-341

Clark, T.H. and Lee, H.G. (2000), "Performance, interdependence and coordination in business-to-business electronic commerce and supply chain management", Information Technology and Management, Vol. 1 No 1/2, pp. 85-105.

Cohen, M. A., \& Lee, H. L. (1988). Strategic analysis of integrated production distribution systems: models and methods. Operations Research, 36(2), 216-228.

Crook, T, Ketchen, Jr D, Combs, J \& Todd, S 2008, "Strategic resources and performance: a meta-analysis", Strategic Management Journal, vol. 29, pp. 1141-1154.

Cross, R., Liedtka, J. and Weiss, L. (2005), "A practical guide to social networks", Harvard Business Review, Vol. 83 No. 3, pp. 124-32.

Denham, M. C. "Prediction Intervals in Partial Least Squares," Joumal of Chemometrics (11), 1997, pp. 39-52

Deshpande, A 2012, 'Supply Chain Management Dimensions, Supply Chain Performance and Organizational Performance: An Integrated Framework', International Journal of Business and Management, vol. 7, no. 8, pp2-19.

Dillman, D.A., 1978. Mail and Telephone Surveys: The Total Design Method. Wiley, New York.

Donlon, J. P. (1996). Maximizing value in the supply chain. Chief Executive, 117, 5463.

Dubey, R, Gunasekaran, A \& Papadopoulos, T (2017), "Green supply chain management: Theoretical framework and further research directions", Benchmarking: An International Journal, vol. 24, pp. 184-218.

Fabrigar, L., Wegener, D., MacCallum, R., \& Strahan, E. (1999). Evaluating the use of exploratory factor analysis in psychological research. Psychological Methods, 4 , 272-299.

Fahy, J., \& Smithee, A. (1999). Strategic marketing and the resource based view of the firm. Academy of Marketing Science Review, 10, 1-20.

Falk, R \& Miller, N 1992, A primer for soft modeling. Akron, OH: Univ. Akron Press. 
Fantazy, K, Tipu, S \& Kumar, V 2016, "Conceptualizing the relative openness of supply chain and its impact on organizational performance", Benchmarking: An International Journal, vol. 23, no. 5, pp. 1264-1285.

Fawcett, S, Jones, S \& Fawcett, A 2012, 'Supply chain trust: The catalyst for collaborative innovation', Business Horizons, vol.55, no.2, pp. 163-178.

Fornell, C \& Larcker, D 1981, 'Evaluating structural equation models with unobservable variables and measurement error', Journal of Marketing Research, vol. 18 , no. 1 , pp. 39-50.

Fox, M, Barbuceanu, M \& Teigen, R 2000, 'Agent-oriented supply-chain management', International Journal of Flexible Manufacturing Systems, vol. 12, no. 2,3, pp. $165-88$.

Gefen, D., Rigdon, E. E., \& Straub, D. (2011). Editor's comments: an update and extension to SEM guidelines for administrative and social science research. MIS Quarterly, iii-xiv.

Gelei, A. 2006. Supplier types and their core competencies in Hungarian automotive supply chains. Doctoral dissertation, Corvinus University of Budapest

Green, K. W., McGaughey, R., \& Casey, M. (2006). Does supply chain management strategy mediate the association between market orientation and organizational performance? Supply Chain Management Journal, 11(5), 407-414.

Grossman, M. (2004), “The role of trust and collaboration in the internet-enabled supply chain", Journal of American Academy of Business, Vol. 5 Nos 1/2, pp. 391-397

Gunasekaran, A, Patel, C \& Tirtiroglu, E 2001, 'Performance measures and metrics in a supply chain environment'. International Journal of Operations \& Production Management, vol. 21, no. 1/2, pp71-87.

Hair, J, Anderson, R, Tatham, R \& Black, W (eds) 1998, Multivariate data analysis, 5th edn, Prentice Hall, Upper Saddle River, NJ.

Hair, J, Black, W \& Babin, B 2010, Multivariate Data Analysis: A Global Perspective, Pearson Education.

Hair, J, Hult, G, Ringle, C \& Sarstedt, M 2014, A Primer on Partial Least Squares Structural Equation Modeling, Sage, Thousand Oaks

Hair Jr, J., Sarstedt, M., Hopkins, L., \& G. Kuppelwieser, V. (2014). Partial least squares structural equation modeling (PLS-SEM) An emerging tool in business research. European Business Review, 26(2), 106-121. 
Hamel, G 1991, "Competition for competence and inter-partner learning within international strategic alliances", Strategic Management Journal, vol. 12, no. 4, pp.83-103.

Handfield, R \& Bechtel, C 2002, 'The role of trust and relationship structure in improving supply chain responsiveness', Industrial Marketing Management, vol. 31, no. 4, pp367-82.

Handfield, R. B., Krause, D. R., Scannell, T. V., \& Monczka, R. M. (2000). Avoid the Pitfalls in Supplier Development. Sloan Management Review, 41, 37-49.

Hausman, W. H. 2004. Supply chain performance metrics in T. P. Harrison, H. L. Lee, J. J. Neale (Eds.). The practice of supply chain management: where theory and application converge. Springer, US, 61-73.

Hu, L. T., Bentler, P. M., and Kano, Y. "Can Test Statistics in Covariance Structure Analysis Be Trusted?," Psychological Bulletin (112), 1992, pp. 351-362

Hui, B. S., and Wold, H. "Consistency and Consistency at Large in Partial Least Squares Estimates," in Systems Under Indirect Observation, Part II, K. G. Joreskog and H. Wold (eds.). North Holland, Amsterdam, 1982, pp. 119-130

Kerlinger, F. N. (1992). Foundations of behavioural research. New York : Holt, Rinehart, and Winston

Kim, D \& Lee, R 2010, Systems Collaboration and Strategic Collaboration: Their Impacts on Supply Chain Responsiveness and Market Performance, Decision Sciences, vol. 41, no. 4, pp 955-981.

Kim, Jae-on \& Charles W. Mueller. (1978). Factor analysis: statistical methods and practical issues. Beverly Hills, Calif.: Sage Publications.

Kim, S. W. (2006). "Effects of Supply Chain Management Practices, Integration and Competition Capability on Performance," Supply Chain Management: An International Journal. 11(3), 241-8.

Lambert, D. M., \& Cooper, M. C. (2000). Issues in supply chain management. Industrial Marketing Management, 29, 65-83.

Lee, H.L., 2004, “The triple-a supply chain”, Harvard Business Review 83, pp. 102112.

Leonczuk, D (2016). Categories of supply chain performance indicators: an overview of approaches, Business, Management and Education, 14(1): 103-115 
Li, S., Nathan, B. R., Nahan, T. S. \& Rao, S. S. (2005). Development and validation of a measurement instrument for studying supply chain management practices. Journal of Operations Management, 23(6), 618-641.

Lin, C., Chow, W. S., Madu, C. N., Kuei, C.-H., \& Yu, P. P. (2005). A structural equation model of supply chain quality management and organizational performance. International Journal Production Economics, v.96, n.3, p.355-365.

Macroulides G.A. \& Saunders C. (2006) Editor's Comments: PLS: A Silver Bullet?. MIS Quarterly, Vol. 30, No. 2, pp. iii-ix

Mafini, C \& Loury-Okoumba, W, (2018), "Extending green supply chain management activities to manufacturing small and medium enterprises in a developing economy", South African Journal of Economic and Management Sciences, Vol.21, no.1, pp. 2-12.

Masudin, I, Wastono, T \& Zulfikarijah, F 2018, “The effect of managerial intention and initiative on green supply chain management adoption in Indonesian manufacturing performance", Cogent Business \& Management, vol.5, pp. 1-19.

McKelvey, B. (2006). Van De Ven and Johnson's “engaged scholarship": Nice try, but.... Academy of Management Review, 31(4), 822-829.

Michalski, M., Montes-Botella, J. L., \& Narasimhan, R. (2018). The impact of asymmetry on performance in different collaboration and integration environments in supply chain management. Supply Chain Management: An International Journal, 23(1), 33-49.

Min, S., Roath, A., Daugherty, P.J., Genchev, S.E., Chen, H. and Arndt, A.D. (2005), “Supply chain collaboration: what's happening?", International Journal of Logistics Management, Vol. 16 No. 2, pp. 237-256.

Moberg, C, Culter, B, Cross, A \& Speh, T 2002, 'Identifying antecedents of information exchange within supply chains', International Journal of Physical Distribution and Logistics Management, vol. 32, no. 9, pp755-70.

Moberg, C. R., \& Speh, T. W. (2003). Evaluating the relationship between questionable business practices and the strength of supply chain relationships. Journal of Business Logistics, 24(2), 1-19.

Neely, A, Gregory, M \& Platts, K 1995, 'Performance measurement system design'. International Journal of Operations \& Production Management, vol. 15, no. 4, pp80-116. 
Newbert, S. L. (2007). Value, rareness, competitive advantage, and performance: A conceptual-level empirical investigation of the resource-based view of the firm. Strategic Management Journal, 29(7), 745-768

Newson, R 2005, Link Function and Probit Analysis, Data Analysis II, Statalist.

Okongwu, U, Lauras, M, Dupont, L \& Humez, V (2012). A decision support system for optimising the order fulfilment process, Production Planning \& Control, Vol. 23, No. 8, 581-598

Pallant, J 2011, SPSS Survival manual: A step by step guide to data analysis using SPSS for windows, 4rd edn, Open University Press, McGraw Hill.

Powell T.C. Competitive advantage: logical and philosophical considerations. Strategic Management Journal, 22(9), 2001, pp. 875-888.

Prahinski, C. and Benton, W.C. (2004), "Supplier evaluations: communication strategies to improve supplier performance”, Journal of Operations Management, Vol. 22 No. 1, pp. 39-62.

Reinartz, W, Haenlein, M \& Henseler, J 2009, 'An Empirical Comparison of the Efficacy of Covariance-based and Variance-based SEM', INSEAD Working Paper Series. MKT(44), pp.1-51.

Ringle, C., Sarstedt, M., Straub, D., (2012), Editor's Comments: A Critical Look at the Use of PLS-SEM in MIS Quarterly, MIS Quarterly Vol. 36 No. 1, pp.iii-s7.

Sabath, R.E. and Autry, C.W. (2001), “Automatic replenishment programs: the impact of organizational structure", Journal of Business Logistics, Vol. 22 No. 1, pp. 91105.

Sahay, B.S. and Mohan, R. (2003), "Supply chain management practices in Indian industry”, International Journal of Physical Distribution \& Logistics Management, Vol. 33 No. 7, pp. 582-606.

Savino, M. M. \& Batbaatar, E. (2015). Investigating the resources for Integrated Management Systems within resource-based and contingency perspective in manufacturing firms. Journal of Cleaner Production, 104 (October, 2015), 392402

Shapiro, J.F. (1999). On the connections among activity-based costing, mathematical programming models for analyzing strategic decisions, and the resource-based view of the firm. European Journal of Operations Research. 118(2), 295-314. 
Shepherd, C \& Gunter, H 2006, 'Measuring supply chain performance: Current research and future directions'. International Journal of Productivity and Performance Management, vol. 55, no. 3/4, pp242-258.

Shin, N.; Park, S.H.; Park, S. (2019) Partnership-Based Supply Chain Collaboration: Impact on Commitment, Innovation, and Firm Performance. Sustainability, 11, 449

Shqairat, A., \& Sundarakani, B. (2018). An empirical study of oil and gas value chain agility in the UAE. Benchmarking: An International Journal, 25(9), 3541-3569.

Singh, A., \& Teng, J. T. C. (2016). Enhancing supply chain outcomes through information technology and trust. Computers in Human Behavior, 54, 290-300.

Soni, G \& Kodali, R 2012, 'A critical review of empirical research methodology in supply chain management', Journal of Manufacturing Technology Management, vol. 23 , no. 6 , pp. $753-779$.

Soosay, C.A., Hyland, P.W. and Ferrer, M. (2008), "Supply chain collaboration: capabilities for continuous innovation", Supply Chain Management: An International Journal, Vol. 13 No. 2, pp. 160-169.

Sudman, S., Bradburn, N., \& Schwarz, N. (1996). Thinking about answers: The Application of cognitive processes to survey methodology. San Francisco, CA: Jossey-Bass.

Sundarakani, B 2017, “Transforming Dubai Logistics Corridor into a Global Logistics Hub", Asian Journal of Management Cases, Vol.14, Issue 2, pp.135-156

Sundarakani, B, Abdul Razzak, H., Manikandan. S. (2018) Creating competitive advantage in the global catering supply chain: a case study of flight catering, International Journal of Logistics: Research and Applications, Vol.21, Issue 5, pp.481-501

Sundarakani, B., (2017) Transforming Dubai Logistics Corridor into a Global Logistics Hub, Asian Journal of Management Cases, Vol.14, Issue 2, pp.135-156.

Sundarakani, B; Sian-Lai, Y; Goh, M; de Souza, R. (2019), Studying the sustainability of third party logistics growth using system dynamics, Journal of Modelling in Management, Vol. 14 No. 4, pp. 872-895

Tan, K. C., Lyman, S. B., \& Wisner, J. D. (2002). Supply chain management: a strategic perspective. International Journal of Operations and Production Management, 22(6), pp.614-631. 
Tenenhaus, M, Vinzi, V, Chatelin, Y \& Lauro, C 2005, 'PLS path modeling', Computational Statistics \& Data Analysis vol. 48, no. 1, pp. 159-205.

Tyndall, Gene, Christopher Gopal, Wolfgang Partsch, and John Kamauff (1998), Supercharging Supply Chains: New Ways to Increase Value Through Global Operational Excellence, New York, NY: John Wiley \& Sons.

Um, K. H., \& Kim, S. M. (2019). The effects of supply chain collaboration on performance and transaction cost advantage: The moderation and nonlinear effects of governance mechanisms. International Journal of Production Economics. Inpress, 2019

Villarreal, B., Garza-Reyes, J.A, Kumar, V. \& Lim, M.K., (2016), Improving road transport operations through lean thinking: a case study, International Journal of Logistics Research and Applications, Vol. 20, Issue. 2, pp.163-180.

Wernerfelt, B. (1984). A resource based view of the firm. Strategic Management Journal, 5, 171-180.

Whitten, G. D.; Green Jr, K. W.; Zelbst, P. J. 2012. Triple-A supply chain performance, International Journal of Operations \& Production Management 32(1), pp28-48.

Wilkens, U., Menzel, D., \& Pawlowsky, P. (2004). Inside the Black-box: Analysing the Generation of Core Competencies and Dynamic Capabilities by Exploring Collective Minds. An Organisational Learning Perspective, Management Review, $15(1), 8-26$.

Wittingslow, G \& Markham, S 1999, 'Customer-Driven Modelling of Satisfaction Behaviour', Australasian Journal of Market Research, vol.7, no.2, pp.29-38.

Wu, W, Chiang, C, Wu, Y \& Tu, H 2004, “The influencing factors of commitment and business integration on supply chain management", Industrial Management \& Data Systems, vol. 104, no. 3/4, pp. 322-33.

Xu, L., \& B. M. Beamon. 2006. "Supply Chain Coordination and Cooperation Mechanisms: An Attribute-based Approach." Journal of Supply Chain Management 42 (1), pp.4-12.

Yap, L. L. \& Tan, C. L. (2012). The Effect of Service Supply Chain Management Practices on the Public Healthcare Organizational Performance. International Journal of Business and Social Science, 3(16), pp.216-224.

Yim, B \& Leem, B 2013, "The effect of the supply chain social capital", Industrial Management \& Data Systems, vol. 113, no. 3, pp.324-349. 


\section{List of Figures}

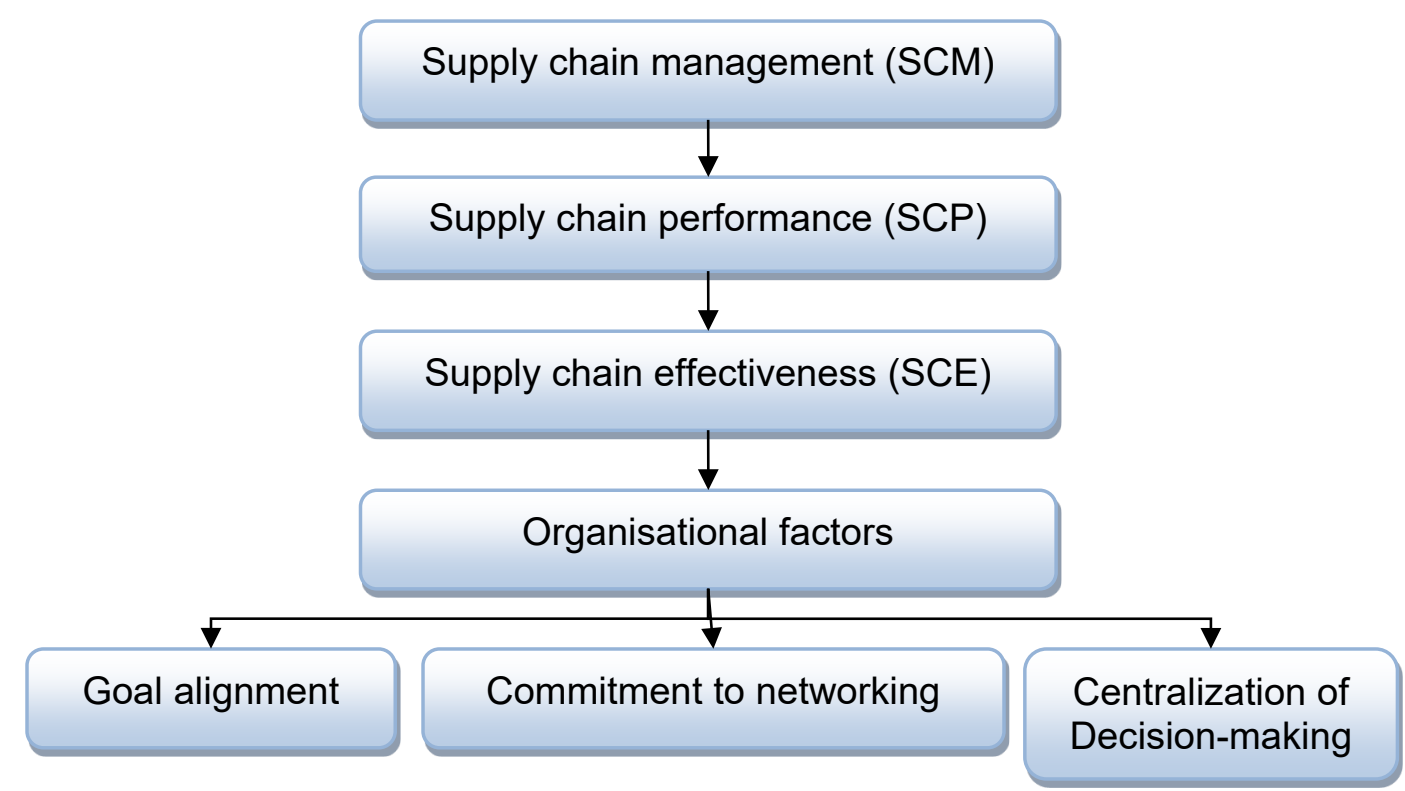

Figure 1: Determinants of Supply Chain Effectiveness 


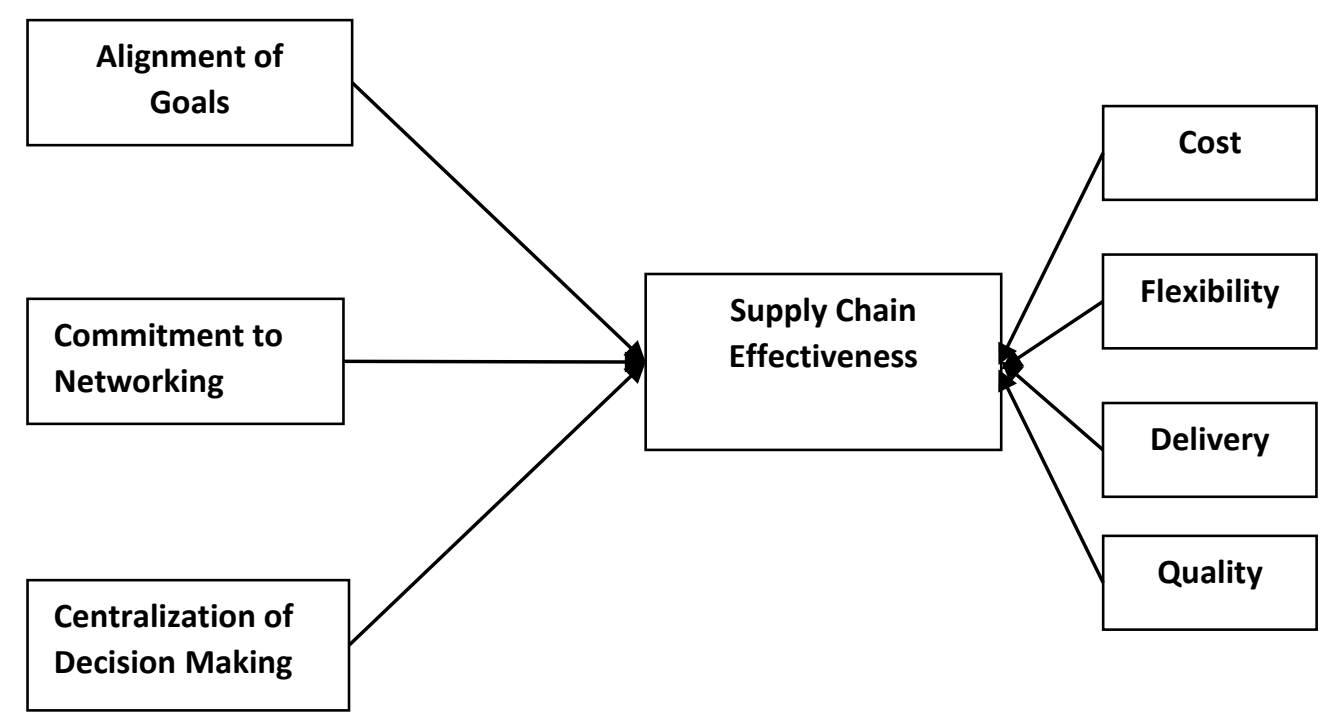

Figure 2. Conceptual framework developed 


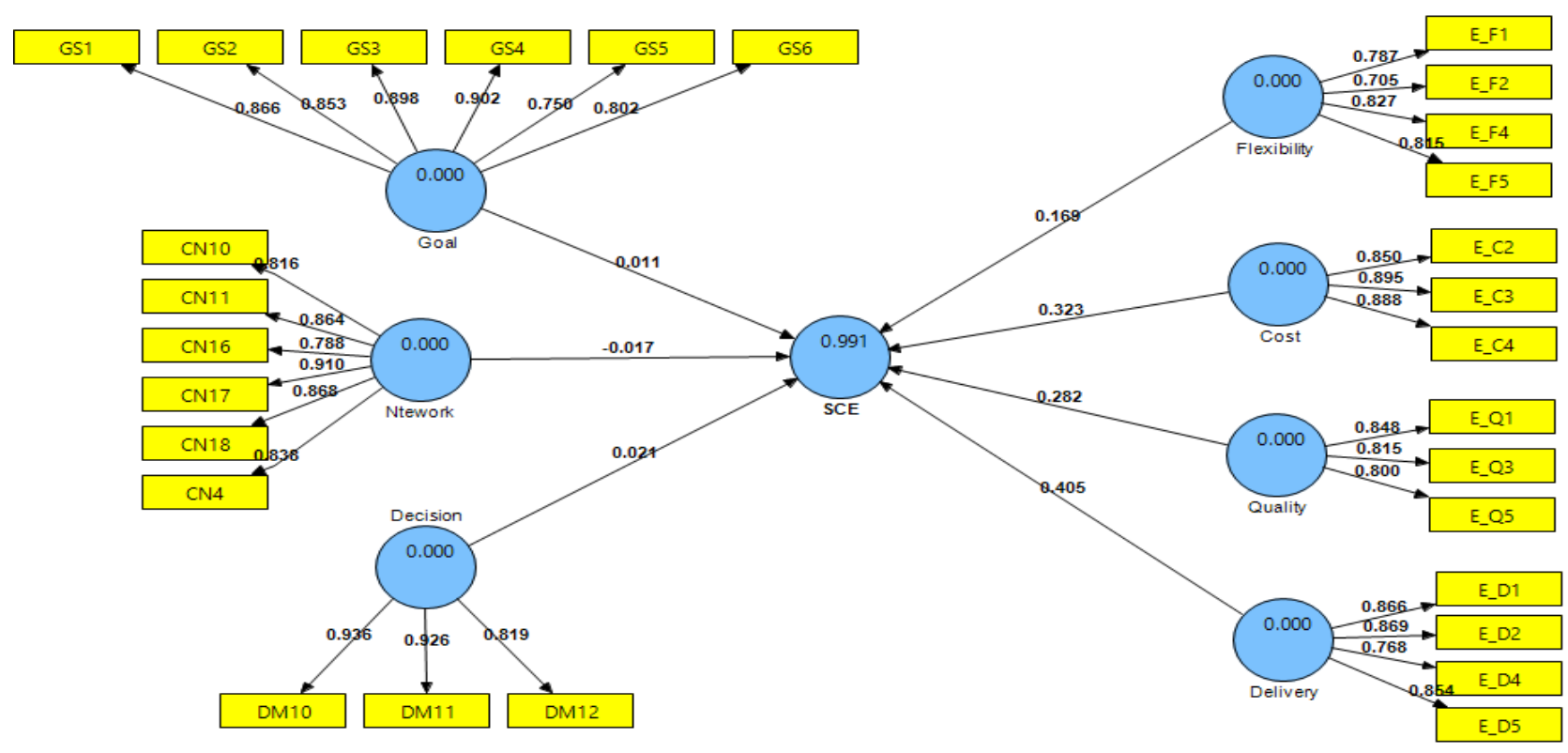

Figure 3 The Measurement Model designed in PLS-SEM 


\section{List of Tables}

Table 1. Summary of Research Gaps

\begin{tabular}{|c|c|c|}
\hline Author & Results/Outcomes & Reflection/Gap \\
\hline $\begin{array}{l}\text { Leonczuk (2016), Singh } \\
\text { (2016) and Arzu Akyuz \& } \\
\text { Erman Erkan (2010) } \\
\text { Fantazy et al. (2016) }\end{array}$ & 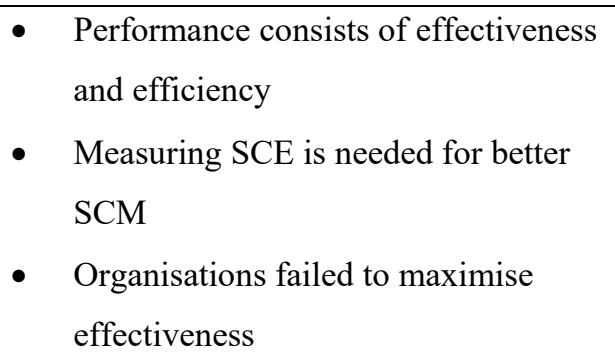 & $\begin{array}{l}\text { SCE is a key aspect of SCP } \\
\text { and needs to be explored }\end{array}$ \\
\hline $\begin{array}{l}\text { Lockamy \& McCormack } \\
\text { (2004), Chen \& Paulraj } \\
\text { (2004), Cousins (2005) and } \\
\text { Beamon (1999) }\end{array}$ & $\begin{array}{l}\text { - Lack of research examining the } \\
\text { relationship among particular SCM } \\
\text { practices and SCP } \\
\text { - } \quad \text { Need to explore others factors of SCP }\end{array}$ & $\begin{array}{l}\text { Research is required into the } \\
\text { factors contributing to SCP }\end{array}$ \\
\hline $\begin{array}{l}\text { Gunasekaran et al. (2001), } \\
\text { Kim et al. (2006), Kim \& } \\
\text { Lee (2010) and Sharma \& } \\
\text { Yu (2010) }\end{array}$ & $\begin{array}{l}\text { - } \\
\text { - } \\
\text { SCE can be determined by measures } \\
\text { such as delivery, cost, flexibility and } \\
\text { quality } \\
\text { - } \\
\text { SCE is understudied in the literature }\end{array}$ & $\begin{array}{l}\text { SCE is not fully explored in } \\
\text { the SCM literature and } \\
\text { research is required to } \\
\text { explore these measures in an } \\
\text { emerging market }\end{array}$ \\
\hline $\begin{array}{l}\text { Kaplan, Norton \& } \\
\text { Rugelsjoen (2010), Min et } \\
\text { al. (2005), Soosay et al. } \\
\text { (2008), Sahay \& Mohan } \\
\text { (2003), Babbar et al. (2008) } \\
\text { and Deshpande (2012) }\end{array}$ & 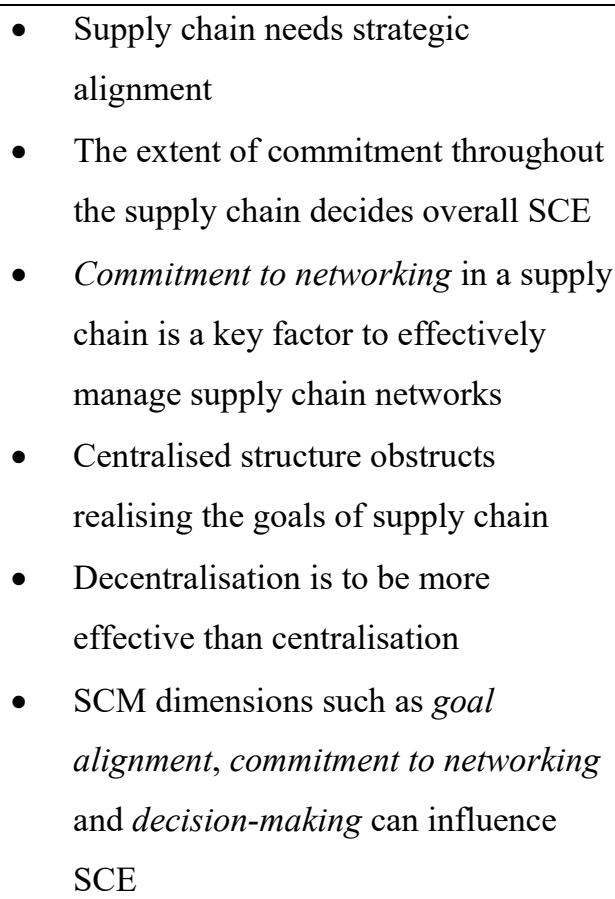 & $\begin{array}{l}\text { Goal alignment, } \\
\text { commitment to networking } \\
\text { and decision-making might } \\
\text { have influence on SCE and } \\
\text { should be researched }\end{array}$ \\
\hline
\end{tabular}

Note: SCE = supply chain effectiveness; SCM = supply chain management; SCP = supply chain performance. 
Table 2: Scale Development Process

\begin{tabular}{llll}
\hline & State of scale development & Source of data & Provides evidence for \\
\hline Stage 1 & Defining the constructs and & Literature review & Face and content validity \\
& generating an item pool & & Understanding the concepts \\
Stage 2 & Determining the format for & Literature review & Reliability (internal) \\
& measurement & & \\
Stage 3 & Judging of items by experts & Experts judges $(\mathrm{n}=3)$ & Face and content validity \\
Stage 4 & Designing a scale and pilot & Pilot study $(\mathrm{n}=25)$ & Face and content validity \\
& test & & \\
Stage 5 & Assessing and finalising the & Survey $(\mathrm{n}=154)$ & Dimensionality (factor analysis) \\
& scale & & and reliability (Cronbach's $\alpha)$ \\
\hline
\end{tabular}


Table 3: Questionnaire Item Descriptions

\begin{tabular}{|c|c|c|c|}
\hline Construct & No. & Question & Source \\
\hline & \multicolumn{2}{|r|}{ In your opinion, which of the following are the main elements that reflect supply chain effectiveness? } & \\
\hline \multirow{7}{*}{ Flexibility } & 1 & Service flexibility & \multirow{20}{*}{$\begin{array}{l}\text { Miguel \& Brito } \\
(2011) \\
\text { Yim \& Leem (2012) } \\
\text { Fantazy et al. } \\
(2016)\end{array}$} \\
\hline & 2 & Product and process flexibility & \\
\hline & 3 & Level of customisation & \\
\hline & 4 & Supply chain flexibility & \\
\hline & 5 & Supply chain agility & \\
\hline & 6 & Use of technology & \\
\hline & 7 & Government rules and regulations & \\
\hline \multirow{5}{*}{ Quality } & 1 & Product and service performance & \\
\hline & 2 & Number of non-conformity & \\
\hline & 3 & Conformance to design specification & \\
\hline & 4 & Customer complaints & \\
\hline & 5 & Time to solve customer complaints & \\
\hline \multirow{5}{*}{ Cost } & 1 & Supply chain cost & \\
\hline & 2 & Inventory turnover & \\
\hline & 3 & Capacity utilisation & \\
\hline & \begin{tabular}{|l|}
4 \\
\end{tabular} & Productivity & \\
\hline & 5 & Government incentives & \\
\hline \multirow{3}{*}{ Delivery } & 1 & Delivery performance & \\
\hline & 2 & On-time delivery & \\
\hline & 3 & Delivery delay & \\
\hline
\end{tabular}




\begin{tabular}{|c|c|c|c|}
\hline Construct & No. & Question & Source \\
\hline & 4 & Access to market & \\
\hline & 5 & Customer order processing time & \\
\hline \multirow{14}{*}{$\begin{array}{l}\text { Goal } \\
\text { alignment }\end{array}$} & 1 & Our organisation shares our goals for business with supply chain partners & \multirow{14}{*}{ Newly developed } \\
\hline & 2 & Our organisation and supply chain partners often agree on what is in the best interest of the relationship & \\
\hline & 3 & Our organisation is enthusiastic about pursuing collective goals and missions with supply chain partners & \\
\hline & 4 & Our organisation works together to achieve common goals with supply chain partners & \\
\hline & 5 & Our organisation measures our success as directly dependent upon the success of supply chain partners & \\
\hline & 6 & Our organisation has compatible goals with supply chain partners & \\
\hline & 7 & Our organisation goals are well aligned with overall supply chain goals & \\
\hline & 8 & There is a mismatch existing between our organisation goals and supply chain goals & \\
\hline & 9 & Our organisation's top management has a clear understanding of supply chain needs and requirements & \\
\hline & 10 & $\begin{array}{l}\text { Our organisation's top management gives the time and resources to support suppliers who are willing to } \\
\text { stay in a long-term partnership with the company }\end{array}$ & \\
\hline & 11 & Our organisation's top management understands the value of supply chain processes and its outcome & \\
\hline & 12 & $\begin{array}{l}\text { To ensure overall business and supply chain objectives are being achieved, it is essential for organisations } \\
\text { to align their individual business strategies with their supply chain strategy }\end{array}$ & \\
\hline & 13 & $\begin{array}{l}\text { Our organisation's top management's priorities have an important effect on organisation's overall } \\
\text { effectiveness }\end{array}$ & \\
\hline & 14 & $\begin{array}{l}\text { Organisation's goals have a crucial effect on supply chain activities, such as network, procurement and } \\
\text { outsourcing decisions }\end{array}$ & \\
\hline \multirow{3}{*}{$\begin{array}{l}\text { Commitment } \\
\text { to } \\
\text { networking }\end{array}$} & 1 & Our organisation's relationship with its supply chain partners is long-term in nature & \multirow{3}{*}{ Newly developed } \\
\hline & 2 & Our organisation has a strong sense of loyalty to its supply chain partners & \\
\hline & 3 & Our organisation has a cooperative relationship with its supply chain partners & \\
\hline
\end{tabular}




\begin{tabular}{|c|c|c|c|}
\hline Construct & No. & Question & Source \\
\hline & 4 & Our organisation and supply chain partners have frequent contact on a regular basis & \\
\hline & 5 & $\begin{array}{l}\text { Our organisation and supply chain partners influence each other's decisions through discussion rather than } \\
\text { request and learning }\end{array}$ & \\
\hline & 6 & $\begin{array}{l}\text { Our organisation and supply chain partners jointly work on promotional events, demand forecasts, } \\
\text { inventory, etc }\end{array}$ & \\
\hline & 7 & Our organisation and supply chain partners share criteria to evaluate performance & \\
\hline & 8 & Our organisation and supply chain partners share performance evaluate & \\
\hline & 9 & Our organisation does not mislead supply chain partners & \\
\hline & 10 & Our organisation keeps its word with supply chain partners & \\
\hline & 11 & Our organisation negotiates fairly with supply chain partners by following ethics & \\
\hline & 12 & Our supply chain partners do not always share sufficient information & \\
\hline & 13 & Our organisation views supply chain partner as our ally against competition & \\
\hline & 14 & Our organisation believes supply chain partners' behaviours are trustworthy & \\
\hline & 15 & Our organisation's top management get involved in the collaboration process with supply chain partners & \\
\hline & 16 & Our organisation considers supply chain partners important & \\
\hline & 17 & Our organisation is committed to a relationship with supply chain partners & \\
\hline & 18 & Our organisation intends to keep good (long-term) relationships with supply chain partners & \\
\hline & 19 & Our organisation shares very little internal information with supply chain partners & \\
\hline & 20 & $\begin{array}{l}\text { Successful long-term relationships are dependent on trust and commitment to networking between supply } \\
\text { chain members }\end{array}$ & \\
\hline & 21 & It is essential for organisations to show a sincere commitment towards their various supply chain partners & \\
\hline & 22 & Supply chain members should dedicate efforts to sustain quality supply chain relationships & \\
\hline & 23 & The extent of commitment throughout the supply chain decides the overall supply chain effectiveness & \\
\hline
\end{tabular}




\begin{tabular}{|c|c|c|c|}
\hline Construct & No. & Question & Source \\
\hline & 24 & Supply chain partners have to be committed to each other for their supply chains to be successful & \\
\hline \multirow{12}{*}{$\begin{array}{l}\text { Decision- } \\
\text { making }\end{array}$} & 1 & It is essential for organisations to have centralised decision-making with a focus on a win-win scenario & \multirow{12}{*}{ Newly developed } \\
\hline & 2 & The authority makes decisions for various functions in the supply chain & \\
\hline & 3 & $\begin{array}{l}\text { It is essential for organisations to have highly decentralised decision-making but the common goals should } \\
\text { be taken into consideration }\end{array}$ & \\
\hline & 4 & $\begin{array}{l}\text { The authority and power to make decisions for various functions in the supply chain department should be } \\
\text { retained by top management }\end{array}$ & \\
\hline & 5 & $\begin{array}{l}\text { Supply chain management decisions could be generally classified as strategic long-term decisions that link } \\
\text { to overall corporate strategy }\end{array}$ & \\
\hline & 6 & $\begin{array}{l}\text { Our organisation has centralised decision-making authority for various functions, including supply chain } \\
\text { management }\end{array}$ & \\
\hline & 7 & Final decisions concerning supply chain management should be retained by top management & \\
\hline & 8 & Our organisation's strategy is usually decided by senior executives & \\
\hline & 9 & Our organisation's strategy is usually made in consultation with functional managers & \\
\hline & 10 & All staff in our organisation are involved in the strategy process to some degree & \\
\hline & 11 & All staff in our organisation are involved in the decision-making process to some degree & \\
\hline & 12 & Most staff in our organisation have input into decisions that directly affect them & \\
\hline
\end{tabular}


Table 4 Component Matrix of IVs

\begin{tabular}{|l|c|c|c|}
\hline Item & $\begin{array}{c}\text { Goal alignment Setting } \\
(\text { GS) }\end{array}$ & $\begin{array}{c}\text { Commitment to } \\
\text { Networking (CN) }\end{array}$ & $\begin{array}{c}\text { Decision } \\
\text { Making (DM) }\end{array}$ \\
\hline GS1 & 0.77 & & \\
\hline GS2 & 0.73 & & \\
\hline GS3 & 0.77 & & \\
\hline GS4 & 0.78 & & \\
\hline GS5 & 0.79 & & \\
\hline GS6 & 0.76 & 0.70 & \\
\hline CN4 & & 0.79 & \\
\hline CN10 & & 0.84 & \\
\hline CN11 & & 0.70 & \\
\hline CN16 & & 0.85 & 0.88 \\
\hline CN17 & & 0.82 & 0.87 \\
\hline CN18 & & & 1.326 \\
\hline DM10 & & & $74.4 \%$ \\
\hline DM11 & & & 0.89 \\
\hline DM12 & & 1.911 & \\
\hline Eigenvalue & 0.92 & 0.919 & \\
\hline Cumulative variance explained & & & \\
\hline Cronbach's alpha & & & \\
\hline
\end{tabular}

Table 5 Component Matrix for Supply Chain Effectiveness

\begin{tabular}{|l|c|c|c|c|}
\hline Item & Flexibility & Cost & Quality & Delivery \\
\hline E_F1 & .808 & & & \\
\hline E_F2 & .730 & & & \\
\hline E_F4 & .706 & & & \\
\hline E_F5 & .630 & & & \\
\hline E_C2 & & .808 & & \\
\hline E_C3 & & .803 & & \\
\hline E_C4 & & .682 & & \\
\hline E_Q1 & & & .728 & \\
\hline E_Q3 & & & .730 & \\
\hline E_Q5 & & & .625 & \\
\hline E_D1 & & & & .723 \\
\hline E_D2 & & & & .718 \\
\hline E_D4 & & & & .688 \\
\hline E_D5 & & & & .846 \\
\hline Eigenvalue & 6.635 & 1.335 & 1.128 & 1.008 \\
\hline
\end{tabular}




\begin{tabular}{|l|c|c|c|c|}
\hline Cumulative variance explained & $47.4 \%$ & $56.9 \%$ & $64.3 \%$ & $70.5 \%$ \\
\hline Cronbach's alpha & 0.79 & 0.85 & 0.75 & 0.86 \\
\hline
\end{tabular}

Code: $E_{-} F=$ Effectiveness measure from flexibility; $E_{-} C=$ Effectiveness measure from cost; $E \_Q=$ Effectiveness measure from Quality; E_D = Effectiveness measure from Delivery

Table6 Model Validation Results

\begin{tabular}{|c|c|c|c|c|c|c|}
\hline \multicolumn{2}{|c|}{ Construct } & \multirow{2}{*}{$\begin{array}{c}\text { Item Code } \\
\text { E_F1 }\end{array}$} & \multirow{2}{*}{$\begin{array}{c}\text { Loading } \\
0.75 \\
\end{array}$} & \multirow[t]{2}{*}{$C R$} & AVE & \multirow[t]{2}{*}{$\alpha$} \\
\hline \multirow{14}{*}{$\begin{array}{l}\text { Supply Chain } \\
\text { Effectiveness }\end{array}$} & \multirow{4}{*}{ Flexibility } & & & & \multirow{4}{*}{0.63} & \\
\hline & & E_F2 & 0.69 & \multirow{3}{*}{0.84} & & \multirow{3}{*}{0.71} \\
\hline & & E_F4 & 0.80 & & & \\
\hline & & E_F5 & 0.80 & & & \\
\hline & \multirow{3}{*}{ Quality } & E_Q1 & 0.79 & \multirow{3}{*}{0.86} & \multirow{3}{*}{0.67} & \multirow{3}{*}{0.76} \\
\hline & & E_Q3 & 0.77 & & & \\
\hline & & E_Q5 & 0.82 & & & \\
\hline & \multirow{3}{*}{ Cost } & E_C2 & 0.85 & \multirow{3}{*}{0.91} & \multirow{3}{*}{0.77} & \multirow{3}{*}{0.85} \\
\hline & & E_C3 & 0.91 & & & \\
\hline & & E_C4 & 0.87 & & & \\
\hline & \multirow{4}{*}{ Delivery } & E_D1 & 0.90 & \multirow{4}{*}{0.91} & \multirow{4}{*}{0.71} & \multirow{4}{*}{0.86} \\
\hline & & E_D2 & 0.85 & & & \\
\hline & & E_D4 & 0.77 & & & \\
\hline & & E_D5 & 0.84 & & & \\
\hline \multirow{6}{*}{\multicolumn{2}{|c|}{ Goal alignment }} & GS1 & 0.87 & \multirow{6}{*}{0.94} & \multirow{6}{*}{0.72} & \multirow{6}{*}{0.92} \\
\hline & & GS2 & 0.85 & & & \\
\hline & & GS3 & 0.90 & & & \\
\hline & & GS4 & 0.90 & & & \\
\hline & & GS5 & 0.75 & & & \\
\hline & & GS6 & 0.80 & & & \\
\hline \multirow{3}{*}{\multicolumn{2}{|c|}{ Decision Making }} & DM10 & 0.94 & \multirow{3}{*}{0.92} & \multirow{3}{*}{0.80} & \multirow{3}{*}{0.89} \\
\hline & & DM11 & 0.93 & & & \\
\hline & & DM12 & 0.82 & & & \\
\hline & & CN4 & 0.84 & & & \\
\hline & & CN10 & 0.82 & & & \\
\hline Commitment & etwerking & CN11 & 0.86 & 094 & 72 & 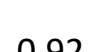 \\
\hline commintrienti & etworking & CN16 & 0.79 & 0.94 & 0.12 & 0.92 \\
\hline & & CN17 & 0.90 & & & \\
\hline & & CN18 & 0.87 & & & \\
\hline
\end{tabular}

Code: $\mathrm{CR}=$ Composite reliability; AVE = Average Variance Extracted; $\alpha=$ Cronbach's $\alpha$ 
Table 7 Shared Variance and Average Variance Extracted

\begin{tabular}{|l|c|c|c|c|c|c|c|c|}
\hline Construct & $\mathbf{1}$ & $\mathbf{2}$ & $\mathbf{3}$ & $\mathbf{4}$ & $\mathbf{5}$ & $\mathbf{6}$ & $\mathbf{7}$ & $\mathbf{8}$ \\
\hline 1 Goal alignment & 0.85 & & & & & & & \\
\hline 2 Organizational Commitment & 0.70 & 0.85 & & & & & & \\
\hline 3 Decision Making & 0.43 & 0.36 & 0.90 & & & & & \\
\hline 4 Flexibility & 0.40 & 0.32 & 0.25 & 0.79 & & & & \\
\hline 5 Cost & 0.30 & 0.21 & 0.24 & 0.59 & 0.88 & & & \\
\hline 6 Quality & 0.35 & 0.37 & 0.30 & 0.60 & 0.60 & 0.82 & & \\
\hline 7 Delivery & 0.35 & 0.40 & 0.20 & 0.59 & 0.62 & 0.65 & 0.84 & \\
\hline 8 Supply Chain Effectiveness & 0.41 & 0.39 & 0.28 & 0.80 & 0.84 & 0.84 & 0.88 & 0.70 \\
\hline
\end{tabular}

Note: Square root of AVE on diagonal and construct correlations below diagonal

Table 8 PLS Results of the Hypotheses Testing

\begin{tabular}{llll}
\hline & Path coefficient $\beta$ & $t$-value & Hypothesis support \\
\hline SCE & $R^{2}=+.20$ & & \\
Goal alignment & $\mathrm{R}^{2}=+.23$ & $2.70^{* * *}$ & Yes \\
Organisational commitment & $\mathrm{R}^{2}=+.19$ & $3.22^{* * *}$ & Yes \\
Decision-making & $\mathrm{R}^{2}=+.12$ & $2.37^{* *}$ & Yes
\end{tabular}

Note: $* * p<.05, * * * p<.01 ; \mathrm{SCE}=$ supply chain effectiveness. 